\title{
Article \\ Laboratory-Scale Research of Non-Catalyzed Supercritical Alcohol Process for Continuous Biodiesel Production
}

\author{
Aso A. Hassan and Joseph D. Smith *(D) \\ Department of Chemical and Biochemical Engineering, Missouri University of Science and Technology, \\ Parker Hall, 106, 300 W 13th St, Rolla, MO 65409, USA; aah2p7@mst.edu \\ * Correspondence: smithjose@mst.edu; Tel.: +1-918-760-1257
}

check for

updates

Citation: Hassan, A.A.; Smith, J.D.

Laboratory-Scale Research of

Non-Catalyzed Supercritical Alcohol

Process for Continuous Biodiesel

Production. Catalysts 2021, 11, 435.

https://doi.org/10.3390/

catal11040435

Academic Editors: José María

Encinar Martín and Sergio

Nogales Delgado

Received: 12 November 2020

Accepted: 26 March 2021

Published: 29 March 2021

Publisher's Note: MDPI stays neutral with regard to jurisdictional claims in published maps and institutional affiliations.

Copyright: (C) 2021 by the authors. Licensee MDPI, Basel, Switzerland. This article is an open access article distributed under the terms and conditions of the Creative Commons Attribution (CC BY) license (https:/ / creativecommons.org/licenses/by/ $4.0 /)$.

\begin{abstract}
This work investigates the non-catalyzed supercritical methanol (SCM) process for continuous biodiesel production. The lab-scale setup was designed and used for biodiesel production in the temperature range of 520-650 $\mathrm{K}$ and 83-380 bar with an oil-to-methanol molar ratio ranging from 1:5 to $1: 45$. The experiments were performed in the coiled plug flow tubular reactor. The volumetric flow rate of the methanol/oil ranged from $0.1-10 \mathrm{~mL} / \mathrm{min}$. This work examines a new reactor technology involving preheating and pre-mixing of the methanol/oil mixture to reduce setup cost and increase biodiesel yield under the same reaction conditions. Work performed showed that FAME's yield increased rapidly with temperature and pressure above the methanol critical points (i.e., $513 \mathrm{~K}$ and 79.5 bar). The best methyl-ester yield using this reaction technology was $91 \%$ at $590 \mathrm{~K}$ temperature and 351 bars with an oil-to-methanol ratio of 39 and a 15-min residence time. Furthermore, the kinetics of the free catalyst transesterification process was studied in supercritical methanol under different reaction conditions.
\end{abstract}

Keywords: supercritical fluids; biodiesel; continuous flow reactor; transesterification

\section{Introduction}

Nowadays, there is a necessity to look for more economical renewable fuels like biodiesel. Biodiesel is an attractive fuel because it is renewable, non-toxic, and biodegradable. It can be used either pure or in blends with diesel fuel; it is also attractive because it can be produced quickly from conventional feedstocks like soybean oil, rapeseed oil, and waste cooking oil. Biodiesel reduces exhaust pollutants like carbon monoxide, hydrocarbons, and particulate matter. However, there is a slight increase in nitrogen oxide emissions. Moreover, biodiesel does not contain aromatics and has almost zero sulfur content.

Despite the above advantages, biodiesel production costs are higher than the petrodiesel fuels. Without government subsidies, biodiesel could not be a profitable fuel, so it is necessary to substitute the refined vegetable oils with an inexpensive triglyceride source such as waste cooking oil [1]. Biodiesel is obtained when a vegetable oil or animal fat chemically reacts with an alcohol to produce fatty acid alkyl esters and glycerol. Generally, the biodiesel production process is known as a transesterification reaction process. The transesterification reaction mechanism is represented in Figure 1. During the reaction, the alkoxy groups in triglyceride molecules exchange with the alkyl group in the alcohol, resulting in the formation of alkyl esters mixtures and glycerol [2-4].

The transesterification reaction process is mainly divided into catalyzed and noncatalyzed methods (as shown in Figure 2). The catalyst could be an enzyme, base, or acid. Both acidic and basic catalysts could be homogeneous or heterogeneous. On the other hand, a non-catalyzed process uses either a supercritical process with high temperature and pressure or a bubble column process with high temperature $[5,6]$. 


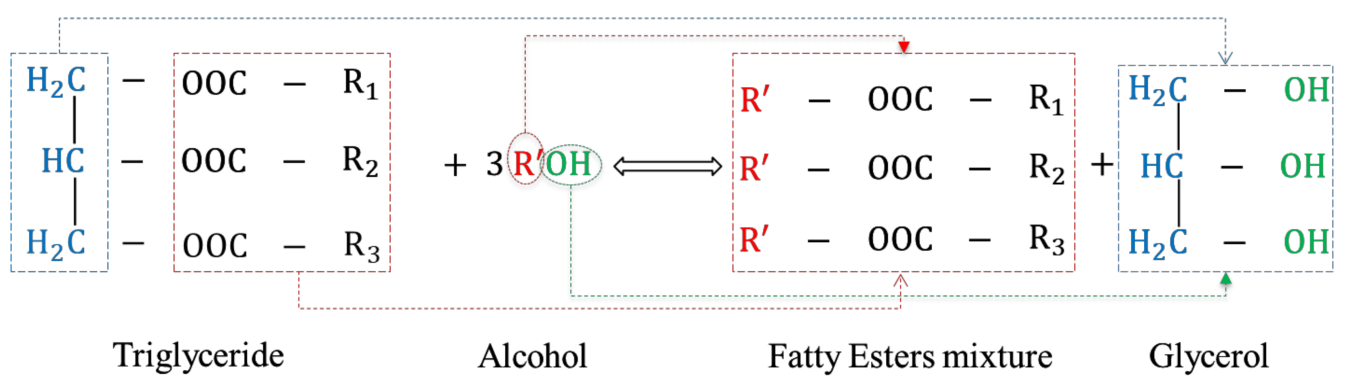

Figure 1. The transesterification reaction mechanism.

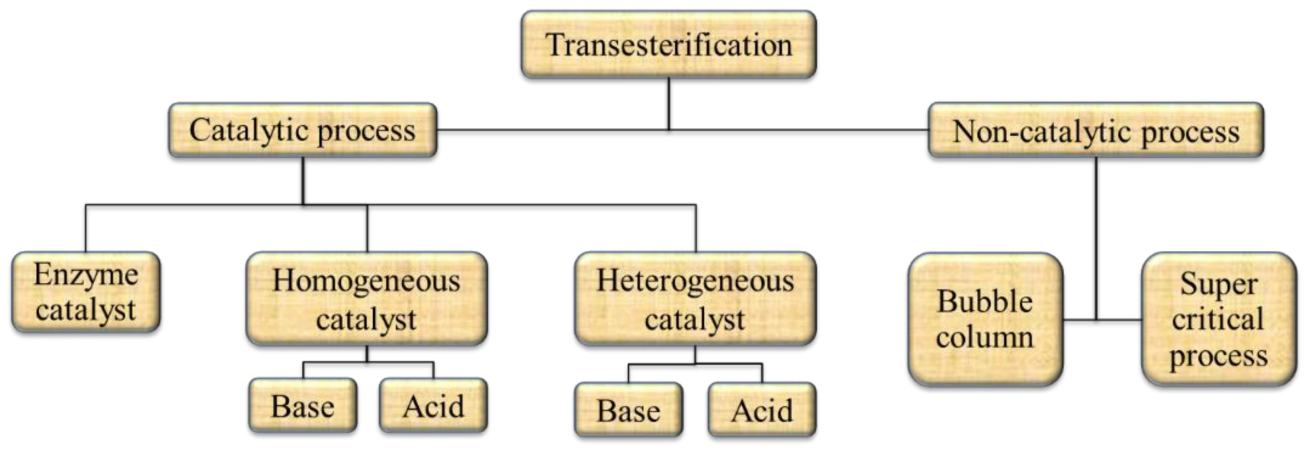

Figure 2. The transesterification processes.

Pure oil has high viscosity and low volatility. Due to this, the oil cannot directly be used as fuel. To overcome these problems, the oil requires slight chemical modifications, including transesterification. All vegetable oils primarily contain triglyceride molecules; there is also a different percentage of di and monoglycerides, free fatty acid (FFA), and water, in some cases, such as WCO. One principal factor is the fossil energy ratio (FER), which is the ratio between the renewable energy outputs from the process per fossil energy input. Biodiesel FER is approximately 3 units of energy for every unit of fossil energy consumed over its life cycle. This is an additional factor that keeps biodiesel such an attractive fuel $[7,8]$.

The conventional biodiesel catalyzed process is the sensitive feedstock process, meaning feedstock containing high FFA and water, which cannot be used directly without an additional pretreatment and sophisticated separation steps. The high temperature of the cooking processes accelerates the triglyceride hydrolysis and increases the FFA. The FFA and water react rapidly with an alcohol in the presence of a base catalyst to produce soap. Additionally, the acid and enzyme-catalyzed process suffer from the long reaction time that takes several hours. The supercritical process successfully addresses the above issues by conducting the transesterification reaction at a temperature and pressure higher than the critical point of the alcohols [9-11]. The supercritical fluid is any substance beyond the critical point. For example, methanol critical temperature and pressure are $240{ }^{\circ} \mathrm{C}$ and 79.5 bar, respectively (as shown in Figure 3).

It is essential to know that close to the critical point, the small changes in pressure or temperature result in substantial changes in density. In general, supercritical fluid has properties between those of a gas and a liquid, and the distinction between them disappears [12,13]. 


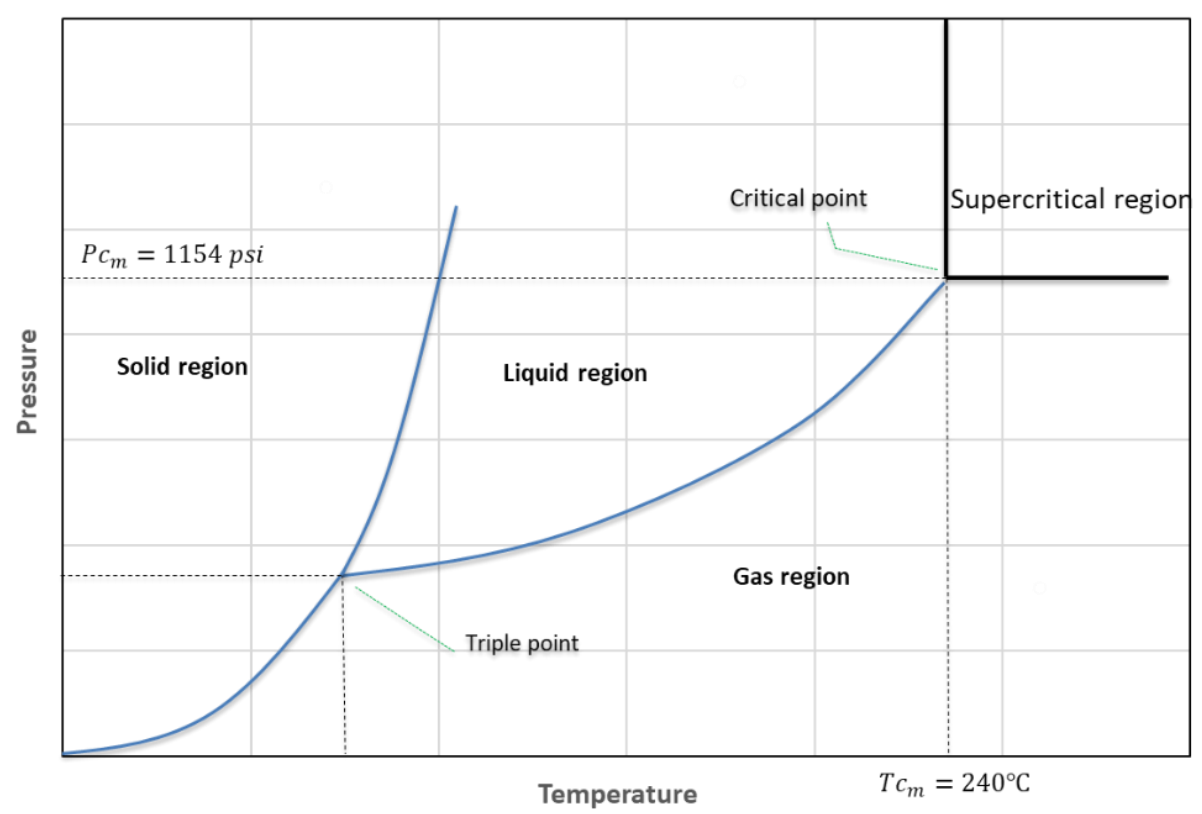

Figure 3. Methanol supercritical point.

Figure 4 illustrates the importance of the biodiesel production process. It makes a comparison between the base-catalyzed process with acid pretreatment steps and the supercritical methanol (SCM) process. The SCM process is much simpler than the catalyzed process. However, the more critical issue is that in the SCM process, no saponified byproduct makes the separation step more complicated, especially with low-grade feedstocks like waste cooking oil (WCO) $[6,14,15]$.

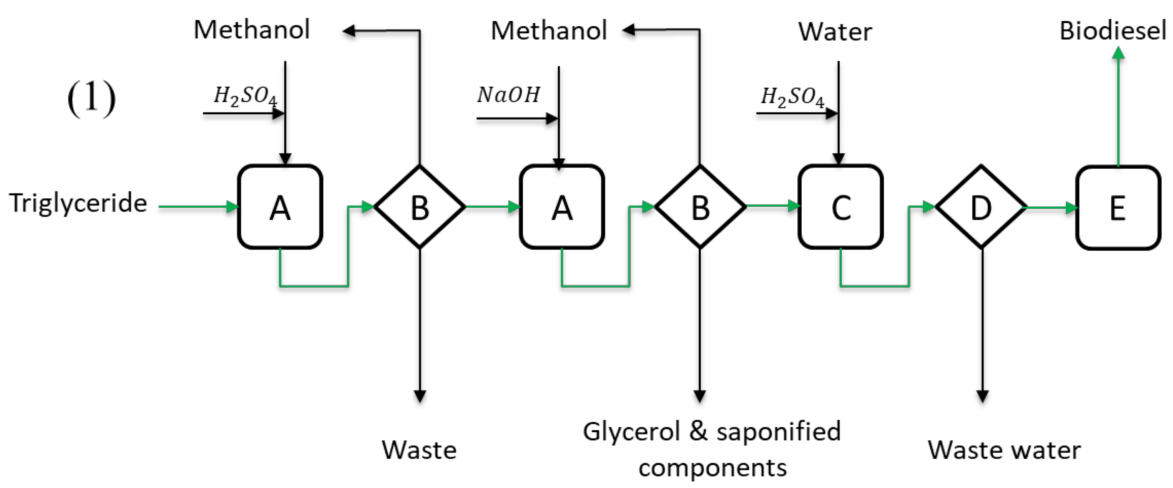

(2)

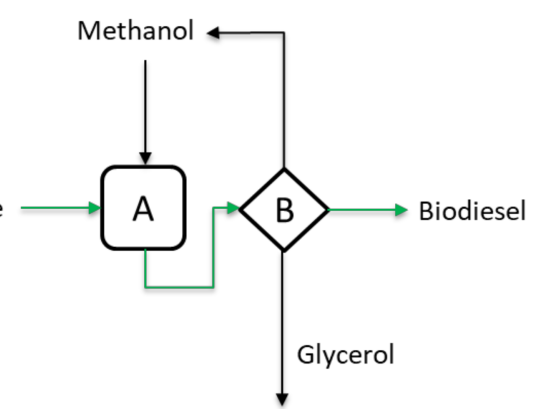
(A) Reactor
(B) Product separation and methanol recovery unit
(C) Water washing unit
(D) Separation unit
(E) Biodiesel drying unit.

Figure 4. The catalyzed process (1) and the super-critical methanol process (2).

Oil and alcohol reactions are known to proceed by three consecutive reaction steps (Equations (1)-(3)), in which the diglyceride formation (Equation (1)) is the rate-limiting step. At low conversion values, the system has mass transfer limitations due to the 
immiscibility of the oil-alcohol. The supercritical method overcomes this problem by forming a single-phase reacting system. The general transesterification reaction process and mechanism are shown in Figure 1 and Equation (4), while the apparent rate constant of the transesterification reaction, $k$, can be given by Equation (5) $[16,17]$.

$$
\begin{gathered}
\mathrm{TG}+\mathrm{AC} \underset{\mathrm{k}_{2}}{\stackrel{\mathrm{k}_{1}}{\Longleftrightarrow}} \mathrm{DG}+\mathrm{FAE} \text { where } \mathrm{r}_{1}=\mathrm{k}_{1}[\mathrm{TG}][\mathrm{AC}] \& \mathrm{r}_{2}=\mathrm{k}_{2}[\mathrm{DG}][\mathrm{FAE}] \\
\mathrm{DG}+\mathrm{AC} \underset{\mathrm{k}_{4}}{\stackrel{\mathrm{k}_{3}}{\Longleftrightarrow}} \mathrm{MG}+\text { FAE where } \mathrm{r}_{3}=\mathrm{k}_{3}[\mathrm{DG}][\mathrm{AC}] \& \mathrm{r}_{4}=\mathrm{k}_{4}[\mathrm{MG}][\mathrm{FAE}] \\
\mathrm{MG}+\mathrm{AC} \underset{\mathrm{k}_{6}}{\stackrel{\mathrm{k}_{5}}{\Longleftrightarrow}} \mathrm{G}+\text { FAE where } \mathrm{r}_{5}=\mathrm{k}_{5}[\mathrm{MG}][\mathrm{AC}] \& \mathrm{r}_{6}=\mathrm{k}_{6}[\mathrm{G}][\mathrm{FAE}] \\
\mathrm{TG}+3 \mathrm{AC} \stackrel{\mathrm{k}_{7}}{\Longleftrightarrow} \mathrm{G}+3 \mathrm{FAE} \\
-\frac{\mathrm{d}[\mathrm{TG}]}{\mathrm{dt}}=\mathrm{k}[\mathrm{TG}]
\end{gathered}
$$

where:

TG is triglycerides.

DG is diglycerides.

MG is monoglycerides.

$\mathrm{AC}$ is alcohol.

FAE is fatty acid ester (biodiesel)

$\mathrm{G}$ is glycerol.

$\mathrm{r}_{1}, \mathrm{r}_{2}, \mathrm{r}_{3}, \mathrm{r}_{4}, \mathrm{r}_{5}$ and $\mathrm{r}_{6}$ are reaction rates

$\mathrm{k}_{1}, \mathrm{k}_{2}, \mathrm{k}_{3}, \mathrm{k}_{4}, \mathrm{k}_{5}, \mathrm{k}_{6}, \mathrm{k}_{7}$, moreover, $\mathrm{k}_{8}$ are reaction constants

It was found that the critical process variables affected the conversion in the supercritical method: temperature, pressure, oil/alcohol ratios, residence time, and mixing and solubility parameters. Among these variables, the most important were considered the temperature, and the pressure since very low yield should be expected at low temperatures and pressure (i.e., below the critical alcohol point). The oil/alcohol ratios were reported to increase the biodiesel production if it was far beyond the theoretical stoichiometric molar ratios of transesterification reactions (i.e., 1:3 see Equation (4)). These factors also interacted with each other; for example, the higher process temperature and pressure led to shorter residence time, but higher biodiesel decompositions and energy consumption should be expected [18].

The mixing and solubility parameters are fundamental in the reactor design and the process operation, since the reactant, the products, and the by-products are only partially soluble in each other. For instance, alcohol is soluble in both biodiesel and glycerol. However, it is partially soluble in the oil. Therefore, when the reaction proceeds and the biodiesel mass fraction increases, the alcohol solubility in the oil-biodiesel phase increases. When biodiesel mass fraction increases to $70 \%$ in the mixture, the oil-alcohol-biodiesel mixture becomes a homogeneous phase. Furthermore, glycerol has high solubility in the alcohol and low solubility in both oil and biodiesel. At the separation unit, two liquid layer phases exist the upper layer rich in biodiesel and the lower layer containing glycerol. The unreacted alcohol is divided between these two layers $[18,19]$.

The triglycerides (TG) conversion to biodiesel is not affected by water and FFA contents in the SC transesterification process. The presence of water and FFA in the reaction mixture even has a positive effect on the reaction yield in the absence of the catalyst. In the low-grade feedstocks with high water and FFA content, the hydrolysis reaction of TG (under the subcritical water condition) will first take place to produce FFA that could be esterified to biodiesel under milder operating conditions compared to the direct SC transesterification process. This reaction procedure certainly reduces energy consumption and decreases the biodiesel project operating cost $[20,21]$. 
Reactor design is a crucial process for improving biodiesel yield and reducing the capital cost of the project. The typical reactor structure used by the continuous process includes a tube, tank, and fixed bed. Zhu et al. [22] obtained more than $96 \%$ biodiesel yield using a tube reactor with an outside diameter of $6 \mathrm{~mm}$ and a length of $6 \mathrm{~m}$. Leevijit et al. [23] designed a six-stage continuous stir tank reactor (CSTR) for palm oil transesterification and concluded that the residence time of 5.98 ideal CSTRs in series was equivalent to a plugflow reactor production performance. He et al. [24] investigated the two fixed-bed reactors with strongly acidic cation exchange resins (NKC-9 cation) and D261 anion-exchange resin, which all proved to return high catalytic activity. Bunyakiat et al. [25] constructed a reactor from SUS316 tubing measuring 217-inches in length with a 3/8 inch outside diameter and 0.035 -inch thickness. The two separate preheated lines for the methanol and the oil were constructed from 79 inches of $1 / 8$ inch outside diameter tubing and were mixed at the reactor inlet with stainless steel tee. They reported 95 and $96 \%$ conversion for coconut and palm kernel oil, respectively. Marulanda et al. [26] investigated the supercritical transesterification of chicken fat in a batch reactor and concluded that at $300-400{ }^{\circ} \mathrm{C}$ reaction temperature, the by-product glycerol was thermally decomposed.

The continuous supercritical transesterification reaction was performed in the coiled plug-flow tubular reactor. In order to enhance the biodiesel yield under the same reaction conditions and reduce the set-up cost, a new reactor technology involving preheating and intensive pre-mixing of the methanol/oil mixture was studied. The continuous reactor was designed in such a way to keep the Peclet number in the range 100-1000 to minimize the back-mixing effects on the conversion of the tubular reactor. In biodiesel production, that demands high conversion value; the low Peclet number could increase the reaction operating condition (i.e., reaction temperature and pressure) and the alcohol/oil ratio, resulting in high production costs. The two-step microwave transesterification process, which includes acid and base catalysts described in an earlier paper, was also examined for comparison purposes.

\section{Results and Discussion}

\subsection{Pressure}

The fatty acid methyl ester (FAME) yield has a relatively high dependence on the pressure and temperature of the reaction. Figure 5 shows the effect of pressure on the transesterification process of supercritical methanol at different temperatures and the molar ratio of oil to methanol at 1:39 in the total residence time of $15 \mathrm{~min}$. The pressures in Figure 5 are all higher than the critical pressure of methanol, which is 79.5 bar. At a pressure slightly higher than the methanol critical pressure, the FAME yield is slightly increasing. However, the FAME yield increased rapidly with the increase in the pressure. The fluid density is also high at elevated pressure, providing a more favorable condition for molecule interaction, and enhancing the oil and the methanol molecule miscibility [25,27]. At the same molar ratio, temperature $(520 \mathrm{~K})$, and residence time, the FAME yield increased from $15 \%$ ( $83 \mathrm{bar}$ ) to $49 \%$ ( $380 \mathrm{bar}$ ), and the pressure makes a noticeable improvement. A further increase in pressure would not lead to a noticeable improvement in the FAME yield. In this study, Figure 5 shows proper reaction conditions for the supercritical transesterification process. The optimal reaction pressure is $351 \mathrm{bar}$. 


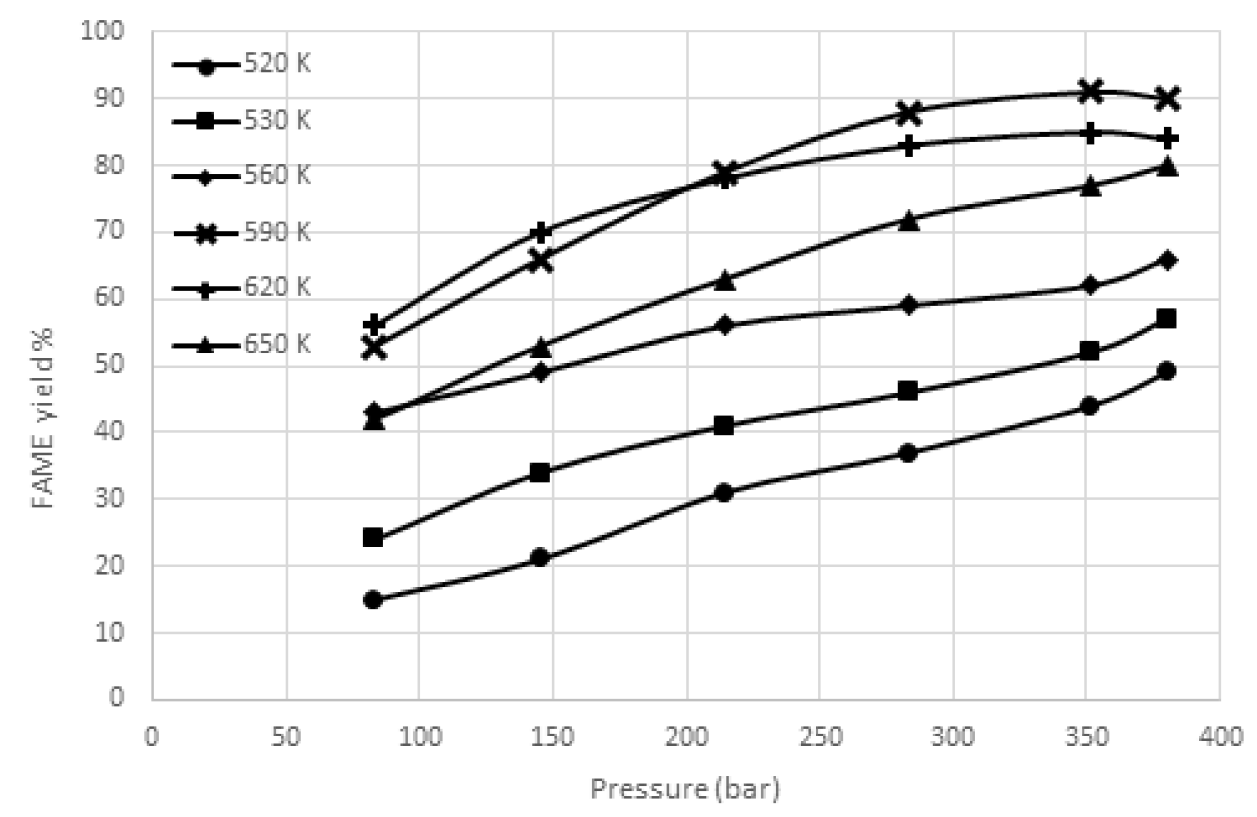

Figure 5. FAME yield (\%) at variable pressure (Time = $15 \mathrm{~min}$ and Molar ratio = 1:39).

\subsection{Temperature}

The effect of temperature on methyl esters yield was well studied in this work, and the result is shown in Figure 6. The supercritical transesterification reaction process was carried out at 351 bar pressure, 1:39 molar ratio, and 15-min residence time. The maximum FAME yield was obtained at $590 \mathrm{~K}$ temperature, and when the temperature increased above $590 \mathrm{~K}$, the FAME yield decreased. The same phenomena can also be observed in Figure 5 and Figure 8. It can be seen in Figure 6 that the yield increased slightly at a temperature close to the methanol critical temperature due to the immiscible behavior of the alcohol and the oil mixture. When the temperature raised to $560 \mathrm{~K}$, the yield increased rapidly from $62 \%$ to $91 \%$ at $590 \mathrm{~K}$. The slight decrease in the FAME yield was observed when the reaction temperature increased above $590 \mathrm{~K}$. These results and phenomena mainly happen due to the thermal degradation and dehydrogenation reactions of the unsaturated FAME that contains two or more double bonds, such as C18:2 and C18:3 [17,22].

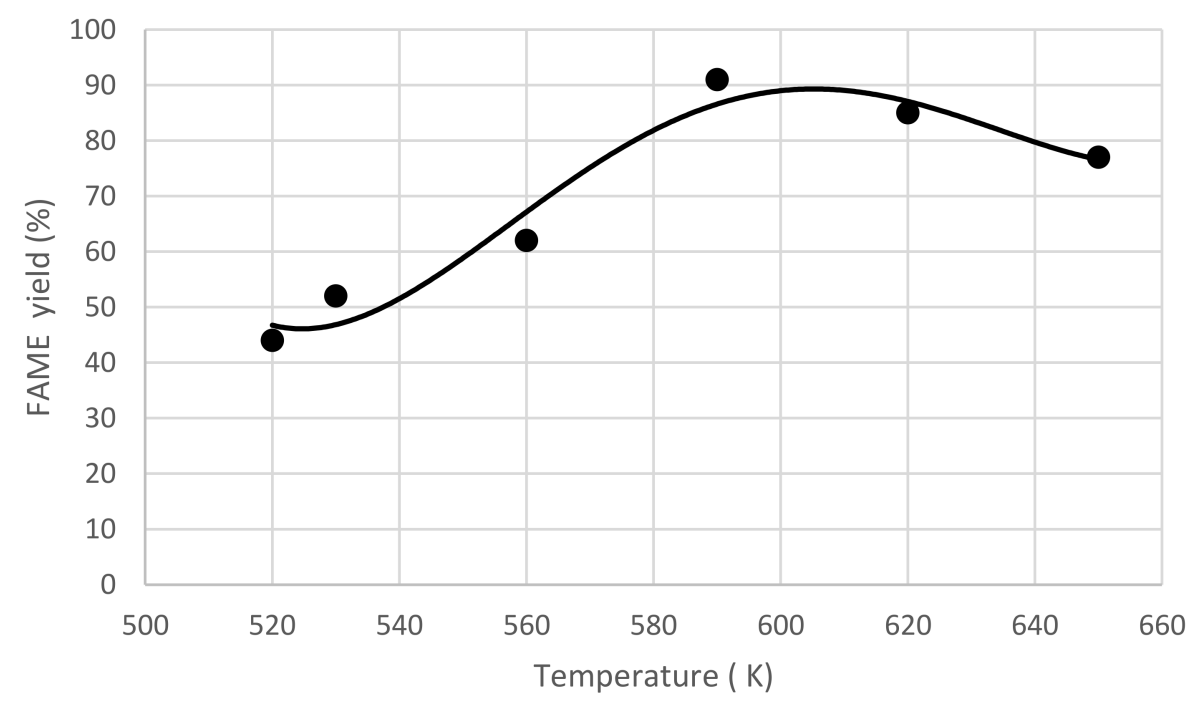

Figure 6. FAME yield $(\%)$ at variable temperature $(\mathrm{P}=351 \mathrm{bar}$, Time $=15 \mathrm{~min}$ and Molar ratio $=1: 39)$. 


\subsection{Molar Ratio}

When the reaction pressure and temperature were fixed at 351 bar and $590 \mathrm{~K}$, respectively, the effect of different oil to methanol ratios on the FAME yield was well studied, and the results are illustrated in Figure 7. Although a supercritical biodiesel production process has several advantages compared to the catalyzed reaction process, the molar ratio is not one of these advantages. In fact, a supercritical process needs high methanol to oil ratio to shift the equilibrium to the product side since the transesterification is a reversible reaction (see Equation (4)). Due to the high methanol concentration, the dielectric constant in the transesterification mixture is close to the value for pure methanol, which is polar material. At the supercritical point, the pure methanol dielectric constant decreases as the temperature increases, and therefore the methanol polarity decreases, and the solubility of non-polar material (oil) in the methanol increases. When the oil dissolves in the methanol completely, the heterogeneous state of the reaction mixture changes to homogeneous due to the high methanol concentration in the reaction mixture. After achieving a particular value of molar ratio that changes the reaction mixture into the homogeneous state, the additional concentration of methanol cannot increase the FAME yield [28,29]. Figure 7 shows that the maximum yield was achieved at 39 methanol to oil ratio, and there was little effect of molar ratio on the FAME yield after that level is reached.

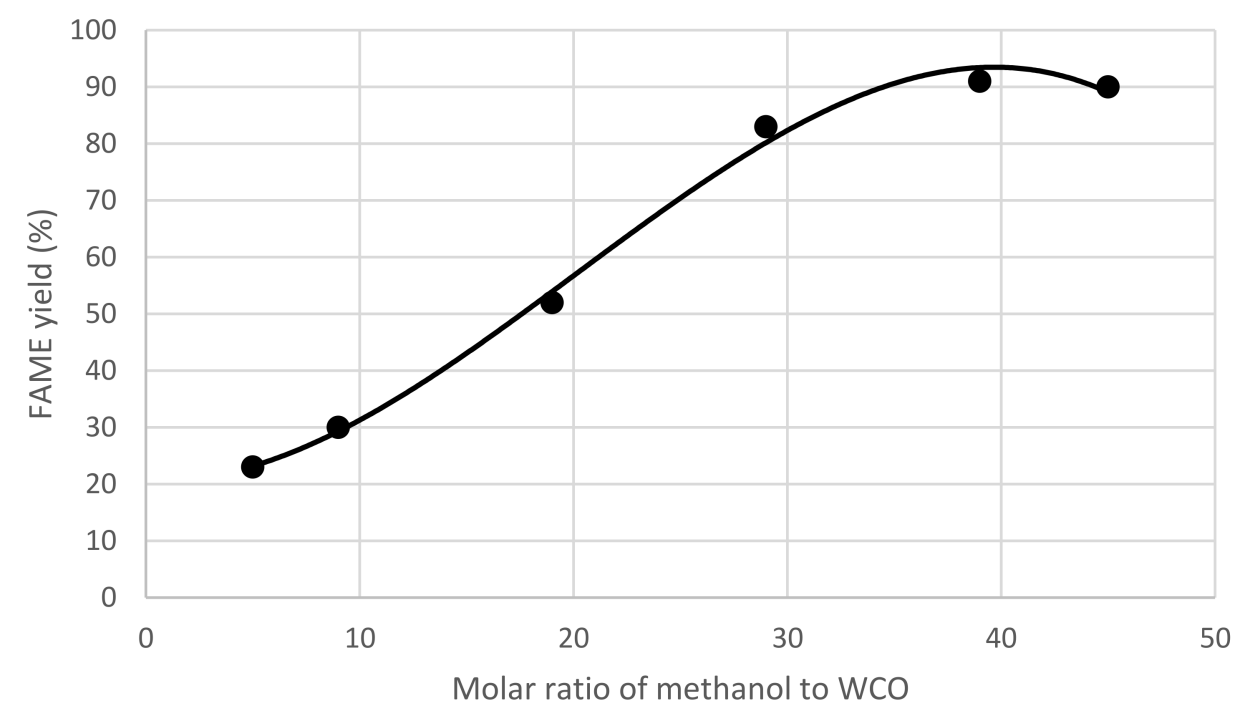

Figure 7. FAME yield (\%) at variable molar ratio $(\mathrm{P}=351 \mathrm{bar}, \mathrm{T}=590 \mathrm{~K}$, Time $=15 \mathrm{~min})$.

\subsection{Residence Time}

The effect of the reaction residence time and temperature on FAME yield were studied, and the results are shown in Figure 8. Time and temperature have a tremendous impact on the biodiesel yield. The results in Figure 8 were carried out at a fixed pressure of 351 bar and oil to a molar ratio of 1:39. Under lower temperature (i.e., $520 \mathrm{~K}$ and $530 \mathrm{~K}$ ), the biodiesel yield slightly increased with time: the yields were $6.2,12.4,24.5,26.3,29.6$, and $32 \%$ at 5 , $10,15,25$, and $30 \mathrm{~min}$, respectively. The FAME yield increased significantly at a higher temperature (i.e., $560 \mathrm{~K}$ ), meaning that the higher FAME yield can be achieved at shorter residence time. However, the maximum yield still cannot be reached even after $30 \mathrm{~min}$. The Biodiesel yields at $560 \mathrm{~K}$ were 66,77 , and $80 \%$ at 20,25 , and $30 \mathrm{~min}$, respectively. When the temperature increased above $560 \mathrm{~K}$ (i.e., 590, 620, and $650 \mathrm{~K}$ ), the transesterification reaction could be sensitive for the residence time and temperature. In other words, when the reaction temperature was $560 \mathrm{~K}$ or lower, the FAME yield increased with the increase in time. However, when the reaction temperature was above $560 \mathrm{~K}$, the FAME yield increased rapidly at the beginning period, then at some inflection point, the FAME yield decreased when the residence time increased. This inflection point in the FAME yield curves is a critical point for the supercritical biodiesel process. The critical point represents 
the equilibrium point between the oil transesterification reaction to FAME and the other side reactions, such as the FAME thermal decomposition and dehydrogenation reactions that reduce the FAME yield. After long residence time and at elevated temperature and pressure, the poly-unsaturated fatty acid in biodiesel partially decomposed to reduce the FAME yield. Furthermore, it has been reported that biodiesel decomposition mainly involves isomerization, polymerization, and pyrolysis reactions, and they occur in the temperature ranges of $275-400{ }^{\circ} \mathrm{C}, 300-425^{\circ} \mathrm{C}$ and $>350{ }^{\circ} \mathrm{C}$, respectively [30-33].

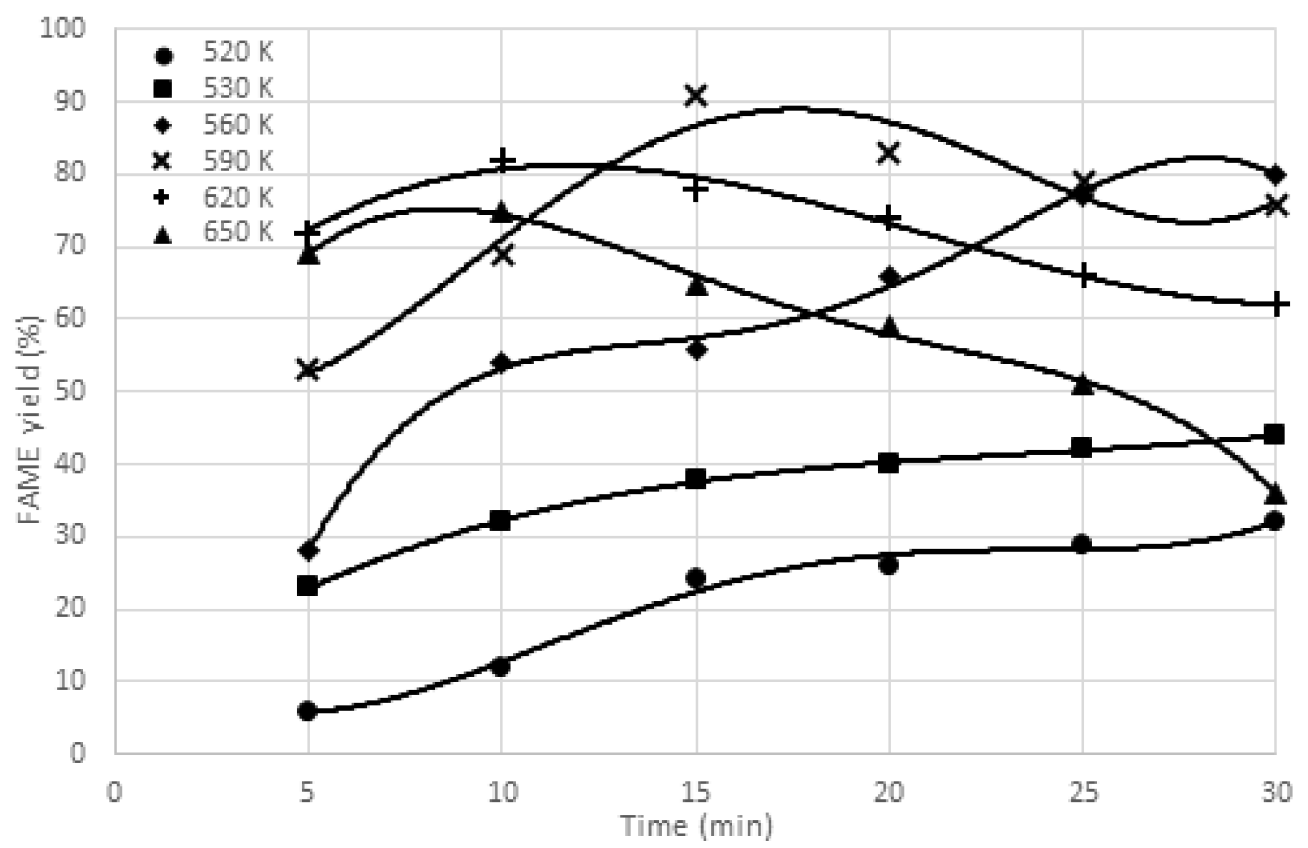

Figure 8. FAME yield $(\%)$ at variable reactor residence time $(\mathrm{P}=351$ bar and Molar ratio $=1: 39)$.

\subsection{Kinetic Model}

The kinetics model was studied at an optimum molar ratio (1:39) as the higher conversion in the supercritical process can be achieved at a high methanol molar ratio. As a result, the reversible transesterification reaction was ignored (see Equation (4)). The transesterification reaction mixtures were grouped into four species: un-esterified compounds ( $\mathrm{uCO})$ that include triglycerides, diglycerides, monoglycerides, and free fatty acids, methanol, glycerin (G) and FAME. Equations (4) and (5) can be rewritten to be

$$
\begin{gathered}
\mathrm{uCO}+\text { Methanol } \stackrel{\mathrm{k}}{\rightarrow} \text { FAME }+\mathrm{G} \\
-\frac{\mathrm{d}[\mathrm{uCO}]}{\mathrm{dt}}=\mathrm{k}[\mathrm{uCO}]
\end{gathered}
$$

Integrating Equation (7) gives Equation (8):

$$
\ln [\mathrm{uCO}, 0]-\ln [\mathrm{uCO}, \mathrm{t}]=\mathrm{kt}
$$

$[\mathrm{uCO}, 0]$ is the initial oil concentration, and $[\mathrm{uCO}, \mathrm{t}]$ is the unreacted oil concentration at time $(\mathrm{t})$. The rate constant can be obtained by linear fitting the experimental data at three different temperatures that give the best and optimum FAME yield using Equation (8). At the optimum operating conditions (i.e., Molar ratio 1:39 and pressure 351 bar), the experimental data showed a good linear relation between $\ln [\mathrm{uCO}, 0]-\ln [\mathrm{uCO}, \mathrm{t}]$ and time (as shown in Figure 9). Figure 10 supports the hypothesis that the supercritical transesterification process can be considered a first-order reaction. The corresponding reaction rate constants were calculated for a three-reaction temperature where excellent linearity is observed. The apparent reaction rate constants in this work are $4.13 \times 10^{-4} \mathrm{~s}^{-1}$, 
$7.32 \times 10^{-4} \mathrm{~s}^{-1}$, and $14.03 \times 10^{-4} \mathrm{~s}^{-1}$ at 560,590 , and $620 \mathrm{~K}$, respectively, and as expected all reaction rate constants increased with temperature. The corresponding Arrhenius plot for the results shown in Figure 9 is presented in Figure 10 to determine the activation energy $(70.59 \mathrm{~kJ} / \mathrm{mole})$. Figure 10 shows the linear relation between the inverse temperature $(x$-axis) and the overall reaction rate constant logarithm ( $y$-axis), implying that the supercritical transesterification process of oil to biodiesel followed the Arrhenius equation. Many authors $[5,17,34,35]$ have reported the reaction rate constants and the activation energy for the supercritical transesterification process. However, these authors used different solvents, different values of molar ratio, and different temperature and pressure ranges than the one used in this work.

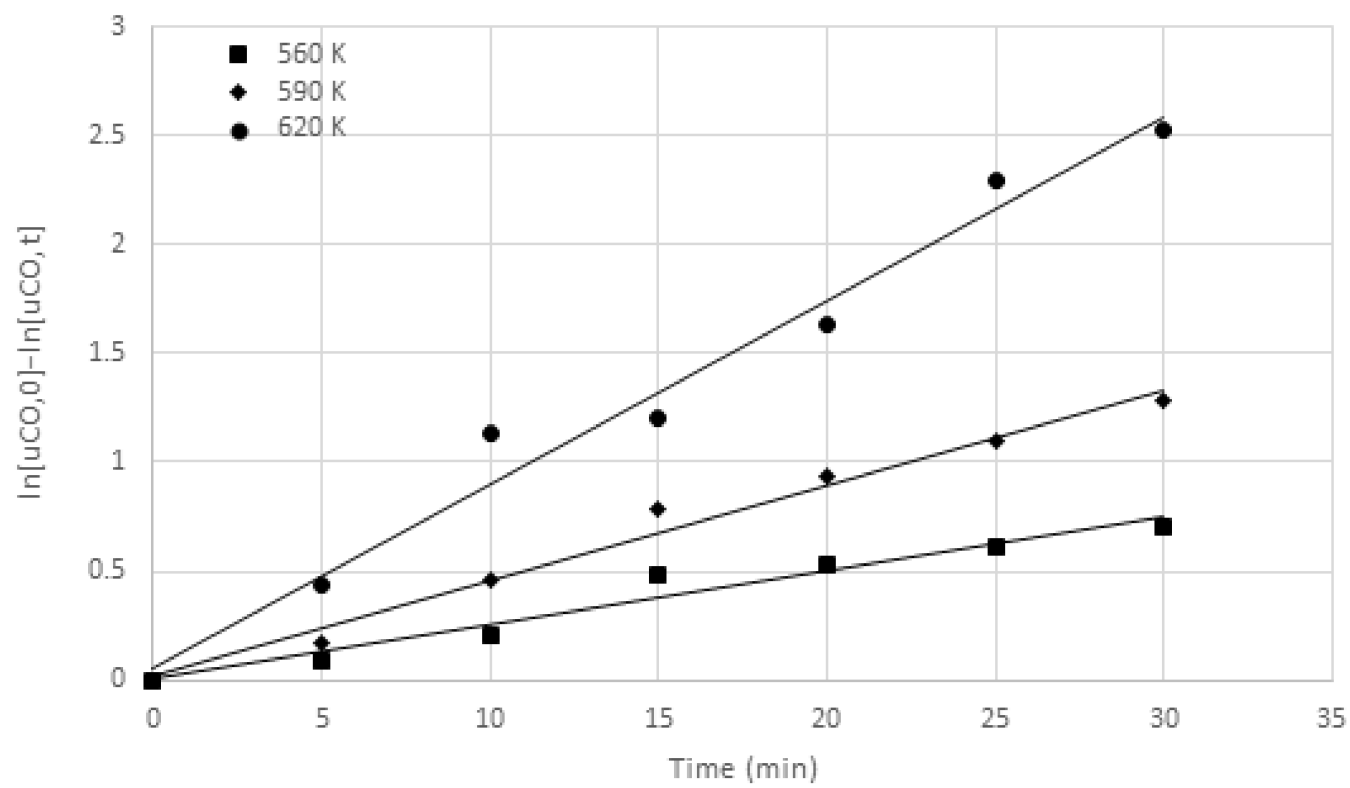

Figure 9. The plot of $\ln [\mathrm{uCO}, 0]-\ln [\mathrm{uCO}, \mathrm{t}]$ value against reaction time at the different reaction temperatures (Molar ratio 1:39 and $\mathrm{P}=351$ bar).

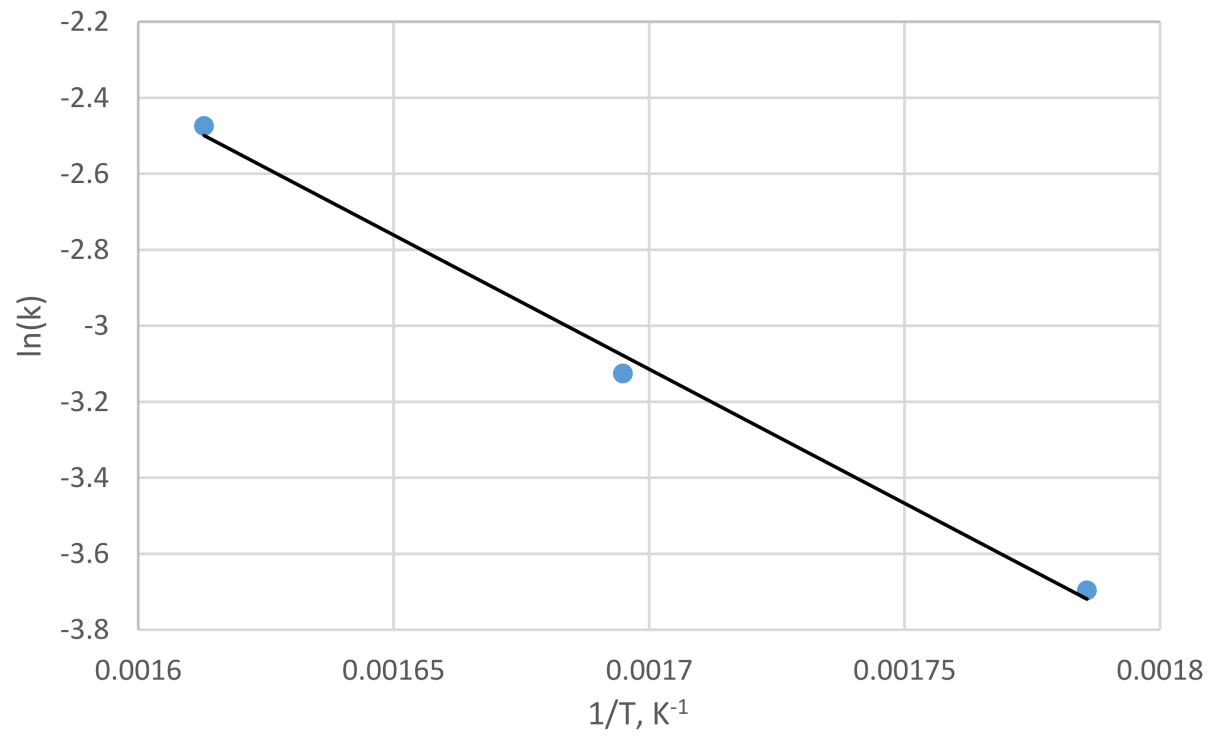

Figure 10. Arrhenius plot for supercritical transesterification reaction (molar ratio 1:39 and $\mathrm{P}=351$ bar). 


\section{Experimental Section}

Figure 11 summarizes the transesterification reaction procedure, showing the reaction starting with methanol and vegetable oil (mostly waste cooking oil) and ending with biodiesel (fatty acid methyl ester) and glycerol as by-products.

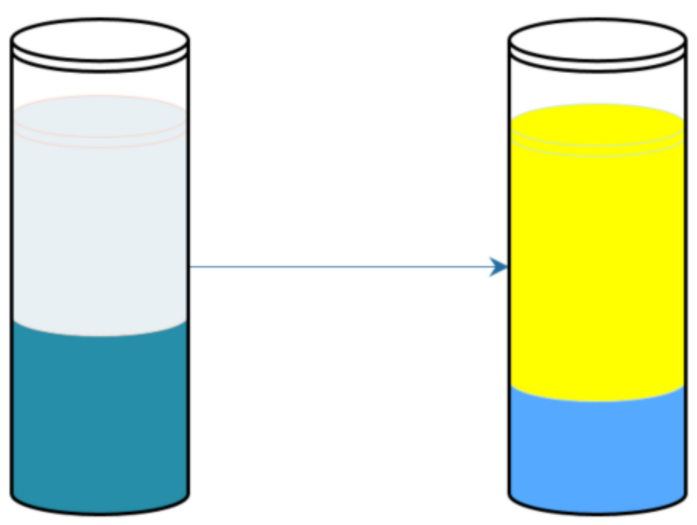

Figure 11. Transesterification's reaction procedure.

\subsection{Materials}

Table 1 illustrated the properties of the collected waste oil in comparison with pure oil. The WCO samples collected from two different sources were mixed and filtered to remove all undesirable and insoluble impurities. Moreover, the samples were heated for $10 \mathrm{~min}$ to $50{ }^{\circ} \mathrm{C}$ to lower the moisture content. The high purity methanol (i.e., $99.8 \%$ ) was used as a solvent in the reaction process.

Table 1. The WCO and Virgin oil properties.

\begin{tabular}{ccc}
\hline Property & WCO & Virgin Vegetable Oil \\
\hline Saponification Value (SV) & 197.8 & 195.4 \\
FFA contents $(\%)$ & 23.26 & 0.87 \\
Kinematic viscosity $\left(\mathrm{mm}^{2} / \mathrm{s}\right)$ & 38.6 & 32.5 \\
Density @ $15^{\circ} \mathrm{C}\left(\mathrm{kg} / \mathrm{m}^{3}\right)$ & 944 & 914 \\
Flash point $\left({ }^{\circ} \mathrm{C}\right)$ & 239 & 209 \\
Acid value $(\mathrm{mg} \mathrm{KOH} / \mathrm{g})$ & 2.3 & 0.4 \\
\hline
\end{tabular}

In Table 2 and column 2 (i.e., the structure column), the first number represents the carbon atoms number and the second number is the double bond number.

Table 2. The fatty acid weight concentration of Virgin Oil and collected WCO.

\begin{tabular}{cccc}
\hline Fatty Acid & Structure & WCO (Wt. \%) & Virgin Oil (Wt. \%) \\
\hline Palmitic Acid & C16:0 & 3.8 & 9.2 \\
Palmitoleic Acid & C16:1 & 3.1 & 0.68 \\
Stearic acid & C18:0 & 2.7 & 4.2 \\
Oleic Acid & C18:1 & 43.7 & 30.6 \\
Linoleic Acid & C18:2 (cis) & 34.7 & 51.1 \\
Linolenic Acid & C18:3 & 9.5 & 3.2 \\
\hline
\end{tabular}

\subsection{Reactor Design}

The 316 SS tubing was used in the reactor construction. The reactor descriptions and dimensions are as follows:

1. The reactor length is 264 inches.

2. The reactor outside diameter is $1 / 8$ inch outside diameter.

3. The reactor inside diameter is 0.040 inch inside diameter. 
4. The reactor ends are coned and threaded; the nipples are provided with highpressure connections (Figure 12).

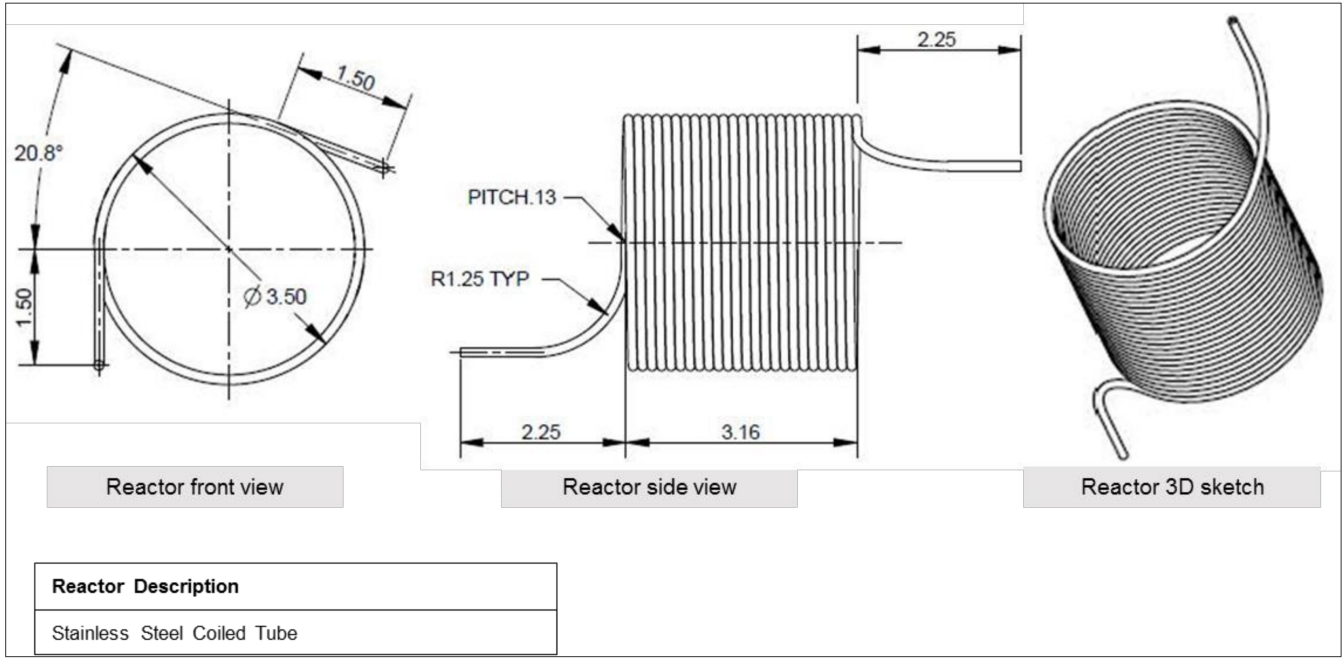

Figure 12. Reactor dimension.

Figure 13 shown the setup details. The first section includes a $1000 \mathrm{~mL}$ Pyrex container provided with a condenser, a chiller with a temperature controller, and an electrical stir heater plate. The second section main equipment is the reciprocating high-pressure pump (Teledyne 6010R, Lincoln, NE, USA), pressure, and flow controllers. The third section is the reactor section that described in Figure 12. Additionally, Section 3 contains a two-way valve, one-way soft seat check valve, two semi-cylinder electrical heater, gas cylinder, temperature controller, and two temperature transmitters. The fourth section is the collecting section, including condenser and chiller, a collection container, temperature transmitter, and backpressure regulator. Figure 13 also shows each stream diameter, the material that it is made from, and the service materials. For example, $0.5-\mathrm{H}_{2} \mathrm{O}-\mathrm{Tef}-\mathrm{N}$ means, 0.5 inches outside diameter, service water, made from Teflon material, and normal pressure, respectively.

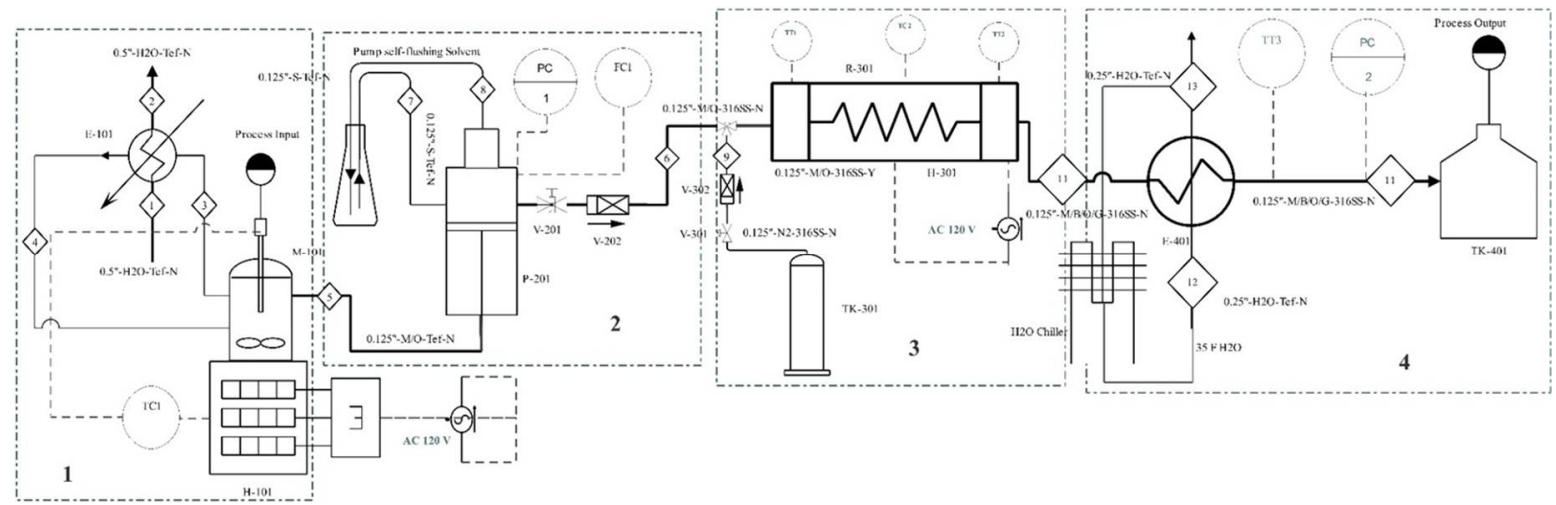

Figure 13. Setup sketch.

\subsection{Setup of Working Producer}

The methanol and oil were mixed in the Section 1 to $50^{\circ} \mathrm{C}$ temperature for $20 \mathrm{~min}$, the mixing temperature was kept lower than the methanol boiling point (i.e., $64.7^{\circ} \mathrm{C}$ ). Then, the reaction mixture was pumped to the reactor by the high-pressure pump. The total flow rate range was between 1 to $10 \mathrm{~mL} / \mathrm{min}$ depending on the residence time and the methanol/oil molar ratio. In Section 4 the product and the by-product was collected and 
cooled in the condenser and depressurized using a back-pressure regulator. Approximately $20 \mathrm{~mL}$ of the liquid product samples were collected.

\subsection{Alcohol Recovery}

The collected reaction sample was treated in the alcohol recovery system to recover the excess methanol. Then, the sample was left overnight to get a complete separation between the glycerol (lower layer) and the biodiesel (upper layer).

Standard Gas-Chromatography (GC) methods determine if the biodiesel conforms to the standard specifications, one of which determines the methyl ester content (EN-14103). The methyl ester concentration was analyzed using an Agilent 7890A gas chromatography equipped with an HP-INNOWAX column $(30 \mathrm{~m} \times 0.25 \mathrm{~mm})$. Approximately $250 \mathrm{mg}$ of product sample is weighted in $10 \mathrm{~mL}$ of the vial, then $5 \mathrm{~mL}$ of methyl heptadecanoate solution $(5 \mathrm{mg} / \mathrm{mL}$ solution of methyl heptadecanoate in heptane) was added to the sample using a pipette. The oven temperature was held for $9 \mathrm{~min}$ at $210^{\circ} \mathrm{C}$ as an isothermal period, then the oven was heated at $20^{\circ} \mathrm{C} / \mathrm{min}$ to $230^{\circ} \mathrm{C}$ and held for $10 \mathrm{~min}$. The ester content $\left(C_{\text {ester }}\right)$, expressed as a mass fraction in percent, was calculated using Equation (9). The methyl ester yield in each experiment was calculated by Equation (10).

$$
C_{\text {ester }}=\frac{\sum A-P M}{P M} \times \frac{M C \times M V}{m} \times 100
$$

where:

$\sum A=$ Sum of the FAME peak area from C14:0 to C24:1;

$P M=$ Peak area of Methylheptadecanoate;

$M C=$ Methyl heptadecanoate solution concentration $(\mathrm{mg} / \mathrm{mL})$;

$M V=$ Methyl heptadecanoate solution volume $(\mathrm{mL})$;

$m=$ mass of the sample (mg).

$$
\text { yield } \%=C_{e s t e r} \times \frac{V_{\text {product }}}{V_{\text {oil fed }}} \times 100
$$

where

$V_{\text {product }}=$ Biodiesel volume;

$V_{\text {oil fed }}=$ Oil volume;

$C_{\text {ester }}=$ Ester content from Equation (10).

\section{Conclusions}

A highly efficient supercritical lab-scale set up in a continuous mode reactor was designed and described for biodiesel production. It was found that the best FAME yield of 91\% was achieved at $590 \mathrm{~K}$ temperature, 351 bar pressure, and 1:39 oil to methanol ratio after 15-min residence time. A first-order kinetic model was proposed, and it has been proven to fit the experimental data very well. In this work, the apparent reaction rate constants for biodiesel production are $4.13 \times 10^{-4} \mathrm{~s}^{-1}, 7.32 \times 10^{-4} \mathrm{~s}^{-1}$, and $14.03 \times 10^{-4} \mathrm{~s}^{-1}$ at 560 , 590 , and $620 \mathrm{~K}$, respectively, and the determined activation energy of the supercritical transesterification reaction is $70.59 \mathrm{~kJ} /$ mole.

Compared to the two-step catalyzed process for biodiesel production, the supercritical process has several advantages. For example, no base or acid catalyst is required for the reaction. Therefore, there is no need for a sophisticated separation process. Additionally, the supercritical process is not sensitive to both water and free fatty acid in the feedstocks. In fact, the free fatty acid in the waste cooking oil could be transesterified simultaneously to increase the FAME yield. Finally, the by-product glycerol from the supercritical process is purer than the catalyzed process glycerol as no soap is produced in the supercritical process. 
Author Contributions: Conceptualization, J.D.S. and A.A.H.; Methodology, A.A.H.; Software, A.A.H.; Validation, J.D.S., A.A.H.; Formal Analysis, A.A.H.; Investigation, A.A.H.; Resources, J.D.S.; Writing-Original Draft Preparation, A.A.H.; Writing-Review and Editing, J.D.S.; Visualization, A.A.H.; Supervision, J.D.S.; Project Administration, J.D.S.; Funding Acquisition, J.D.S. All authors have read and agreed to the published version of the manuscript.

Funding: This research was funded by the Wayne and Gayle Laufer Foundation.

Data Availability Statement: Not applicable.

Acknowledgments: The authors would like to express their gratitude to Eileen Smith for proofing, editing, and reading several previous drafts of this paper and providing many valuable comments that improved the contents of this paper.

Conflicts of Interest: The authors declare no conflict of interest.

$\begin{array}{ll}\text { Abbreviations } & \\ \text { SCM } & \text { Supercritical methanol } \\ \text { WCO } & \text { Waste cooking oil } \\ \text { FFA } & \text { Free fatty acids } \\ \text { FAME } & \text { Fatty acid methyl ester } \\ \text { GHz } & \text { Gigahertz } \\ \text { FER } & \text { Fossil energy ratio } \\ \text { uCO } & \text { Un-esterified compounds } \\ \text { SC } & \text { Supercritical } \\ \text { ASTM } & \text { American Society for Testing and Materials } \\ \text { EN14214 } & \text { European Committee for Standardization } \\ \text { TG } & \text { Triglycerides } \\ \text { DG } & \text { Diglycerides } \\ \text { MG } & \text { Monoglycerides } \\ \text { G } & \text { Glycerol } \\ \text { FAE } & \text { Fatty acid ester } \\ \text { Temperature unit (K) } & \text { Kelvin }\end{array}$

\section{References}

1. Marulanda, V.F.; Anitescu, G.; Tavlarides, L.L. Biodiesel Fuels through a Continuous Flow Process of Chicken Fat Supercritical Transesterification. Energy Fuels 2010, 24, 253-260. [CrossRef]

2. Santana, A.; Maçaira, J.; Larrayoz, M.A. Continuous production of biodiesel from vegetable oil using supercritical ethanol/carbon dioxide mixtures. Fuel Process. Technol. 2012, 96, 214-219. [CrossRef]

3. Santana, A.; Maçaira, J.; Larrayoz, M.A. Continuous production of biodiesel using supercritical fluids: A comparative study between methanol and ethanol. Fuel Process. Technol. 2012, 102, 110-115. [CrossRef]

4. Gui, M.M.; Lee, K.T.; Bhatia, S. Supercritical ethanol technology for the production of biodiesel: Process optimization studies. J. Supercrit. Fluids 2009, 49, 286-292. [CrossRef]

5. Song, E.S.; Lim, J.w.; Lee, H.S.; Lee, Y.W. Transesterification of RBD palm oil using supercritical methanol. J. Supercrit. Fluids 2008, 44, 356-363. [CrossRef]

6. Sawangkeawa, R.; Bunyakiata, K.; Ngamprasertsitha, S. A review of laboratory-scale research on lipid conversion to biodiesel with supercritical methanol (2001-2009). J. Supercrit. Fluids 2010, 55, 1-13. [CrossRef]

7. Pradhan, A.; Shrestha, D.S.; McAloon, A.; Yee, W.; Haas, M.; Duffield, J.A.; Shapouri, H. Energy Life-Cycle Assessment of Soybean Biodiesel; Agricultural Economic Report No. 845; USDA, Office of the Chief Economist, Office of Energy Policy and New Uses: Washington, DC, USA, 2009. Available online: www.usda.gov/oce/reports/energy/ELCAofSoybeanBiodiesel91409.pdf (accessed on 26 March 2021).

8. Ge, J.C.; Yoon, S.K.; Choi, N.J. Using Canola Oil Biodiesel as an Alternative Fuel in Diesel Engines: A Review. Appl. Sci. 2017, 7, 881. [CrossRef]

9. Pinnarat, T.; Savage, P.E. Assessment of Noncatalytic Biodiesel Synthesis Using Supercritical Reaction. Ind. Eng. Chem. Res. 2008, 47, 6801-6808. [CrossRef]

10. Encinar, J.M.; Gonzalez, J.F.; Rodriguez-Reinares, A. Biodiesel from Used Frying Oil. Variables Affecting the Yields and Characteristics of the Biodiesel. Ind. Eng. Chem. Res. 2005, 44, 5491-5499. [CrossRef]

11. Saka, S.; Kusdiana, D. Biodiesel fuel from rapeseed oil as prepared in supercritical methanol. Fuel 2001, 80, 225-231. [CrossRef] 
12. Abdulagatov, I.M.; Polikhronidi, N.G.; Abdurashidova, A.; Kiselev, S.B.; Ely, J.F. Thermodynamic Properties of Methanol in the Critical and Supercritical Regions. Int. J. Thermophys. 2005, 26, 1327-1368. [CrossRef]

13. Dean, J.R. Applications of Supercritical Fluids in Industrial Analysis; Dean, J., Ed.; CRC Press: Newcastle, UK, 1993.

14. Patil, P.; Deng, S.; Rhodes, J.I.; Lammers, P.J. Conversion of waste cooking oil to biodiesel using ferric sulfate and supercritical methanol processes. Fuel 2010, 89, 360-364. [CrossRef]

15. Tran, D.T.; Chang, J.S.; Lee, D.J. Recent insights into continuous-flow biodiesel production via catalytic and non-catalytic transesterification processes. Appl. Energy 2017, 185, 376-409. [CrossRef]

16. Choi, C.S.; Kim, J.W.; Jeong, C.J.; Kim, H.; Yoo, K.P. Transesterification kinetics of palm olein oil using supercritical methanol. J. Supercrit. Fluids 2011, 58, 365-370. [CrossRef]

17. Kusdiana, D.; Saka, S. Kinetics of transesteri ${ }^{\circledR}$ cation in rapeseed oil to biodiesel fuel as treated in supercritical methanol. Fuel 2001, 80, 693-698. [CrossRef]

18. Anitescu, G.; Deshpande, A.; Tavlarides, L.L. Integrated Technology for Supercritical Biodiesel Production and Power Cogeneration. Energy Fuels 2008, 22, 1391-1399. [CrossRef]

19. Oliveira, M.B.; Teles, A.R.R.; Queimada, A.J.; Coutinho, J.A.P. Phase equilibria of glycerol containing systems and their description with the Cubic-Plus-Association (CPA) Equation of State. Fluid Phase Equilibria 2009, 280, 22-29. [CrossRef]

20. García-Martínez, N.; Andreo-Martínez, P.; Quesada-Medina, J.; de los Ríos, A.P.; Chica, A.; Beneito-Ruiz, R.; Carratalá-Abril, J. Optimization of non-catalytic transesterification of tobacco (Nicotiana tabacum) seed oil using supercritical methanol to biodiesel production. Energy Convers. Manag. 2017, 131, 99-108. [CrossRef]

21. Kusdiana, D.; Saka, S. Two-Step Preparation for Catalyst-Free Biodiesel Fuel Production. Appl. Biochem. Biotechnol. 2004, 115, 781-791. [CrossRef]

22. He, H.; Wang, T.; Zhu, S. Continuous production of biodiesel fuel from vegetable oil using supercritical methanol process. Fuel 2007, 86, 442-447. [CrossRef]

23. Leevijit, T.; Tongurai, C.; Prateepchaikul, G.; Wisutmethangoon, W. Performance test of a 6-stage continuous reactor for palm methyl ester production. Bioresour. Technol. 2008, 99, 214-221. [CrossRef]

24. He, B.; Shao, Y.; Ren, Y.; Li, J.; Cheng, Y. Continuous biodiesel production from acidic oil using a combination of cation- and anion-exchange resins. Fuel Process. Technol. 2015, 130, 1-6. [CrossRef]

25. Bunyakiat, K.; Makmee, S.; Sawangkeaw, R.; Ngamprasertsith, S. Continuous Production of Biodiesel via Transesterification from Vegetable Oils in Supercritical Methanol. Energy Fuels 2006, 20, 812-817. [CrossRef]

26. Marulanda, V.F.; Anitescua, G.; Tavlarides, L.L. Investigations on supercritical transesterification of chicken fat for biodiesel production from low-cost lipid feedstocks. J. Supercrit. Fluids 2010, 54, 53-60. [CrossRef]

27. Jiang, J.J.; Tan, C.S. Biodiesel production from coconut oil in supercritical methanol in the presence of cosolvent. J. Taiwan Inst. Chem. Eng. 2012, 43, 102-107. [CrossRef]

28. Campos, D.C.; Dall'Oglio, E.L.; de Sousa, P.T., Jr.; Vasconcelos, L.G.; Kuhnen, C.A. Investigation of dielectric properties of the reaction mixture during the acid-catalyzed transesterification of Brazil nut oil for biodiesel production. Fuel 2014, 117, 957-965. [CrossRef]

29. Muley, P.D.; Boldor, D. Investigation of microwave dielectric properties of biodiesel components. Bioresour. Technol. 2013, 127, 165-174. [CrossRef] [PubMed]

30. Imahara, H.; Minami, E.; Hari, S.; Saka, S. Thermal stability of biodiesel in supercritical methanol. Fuel 2008, 87, 1-6. [CrossRef]

31. Lin, R.; Zhu, Y.; Tavlarides, L.L. Mechanism and kinetics of thermal decomposition of biodiesel fuel. Fuel 2013, 106, 593-604. [CrossRef]

32. Lin, R.; Zhu, Y.; Tavlarides, L.L. Effect of thermal decomposition on biodiesel viscosity and cold flow property. Fuel 2014, 117, 981-988. [CrossRef]

33. Quesada-Medina, J.; Olivares-Carrillo, P. Evidence of thermal decomposition of fatty acid methyl esters during the synthesis of biodiesel with supercritical methanol. J. Supercrit. Fluids 2011, 56, 56-63. [CrossRef]

34. Farobie, O.; Leow, Z.Y.M.; Samanmulya, T.; Matsumura, Y. In-depth study of continuous production of biodiesel using supercritical 1-butanol. Energy Convers. Manag. 2017, 132, 410-417. [CrossRef]

35. Velez, A.; Soto, G.; Hegel, P.; Mabe, G.; Pereda, S. Continuous production of fatty acid ethyl esters from sunflower oil using supercritical ethanol. Fuel 2012, 97, 703-709. [CrossRef] 